\title{
Ny kunnskap om Creutzfeldt-Jakobs sykdom kan gi terapeutiske muligheter
}

\author{
Sammendrag \\ Bakgrunn. Creutzfeldt-Jakobs sykdom \\ er en sjelden, nevrologisk sykdom. Den \\ gir alltid dødelig utgang, ofte i løpet av \\ noen få måneder etter symptomdebut. \\ Sykdommen ble aktualisert i 1990 - \\ årene, da det ble rapportert om men- \\ nesker som var smittet av mat fra \\ storfe med kugalskap. Forskning de \\ senere år har vist oppløftende resulta- \\ ter innen behandling av sykdommen. \\ Vi gir her en oversikt over de mest \\ lovende funnene.
}

\section{Materiale og metode. Artikkelen er basert på ikke-systematiske litteratur- søk i PubMed med et skjønnsmessig utvalg av artikler. Vi har også tatt en gjennomgang av referanselistene i disse artiklene.}

Resultater. Sykdommen oppstår når det naturlige prionproteinet, $\operatorname{PrPC}^{\mathrm{C}}$, blir omdannet til den sykdombetingede scrapievarianten, $\mathrm{PrP}^{\mathrm{Sc}}$. Mus som var genmanipulert slik at de ikke produserte $\mathrm{PrPC}$, utviklet ikke tegn til sykdom etter eksponering for scrapiesmitte. Behandling med antistoffer mot $\mathrm{PrPC}$ og redusert genekspresjon av $\mathrm{PrPC}$ med RNA-interferens-teknikk økte overlevelsestiden i musefors $\emptyset$ k. Pentosanpolysulfat infusert intraventrikulært forlenget tiden fra smitteoverføring til kliniske symptomer fra 51 til 123 dager i et museforsøk. Dette er et medikament mot interstitiell cystitt som har gitt lovende resultater for overlevelsestid i tester på pasienter med Creutzfeldt-Jakobs sykdom.

Fortolkning. Ved å benytte nye angrepsvinkler og behandlingsmetoder har man oppnådd resultater som kan gi håp om kurativ behandling i fremtiden.

\author{
Torger Stølsmark \\ tst070@student.uib.no \\ Det medisinske fakultet \\ Universitetet i Bergen \\ Postboks 7800 \\ 5020 Bergen \\ Ole-Bjørn Tysnes \\ Nevrologisk avdeling \\ Haukeland universitetssykehus \\ Bergen
}

Creutzfeldt-Jakobs sykdom (CJD) er en prionsykdom med en insidens på kun rundt 1-2 per en million per år (1). Likevel har den fătt mye oppmerksomhet fordi den potensielt kan være smittsom. Sykdommen er alltid dødelig, og døden inntreffer ofte i løpet av noen få måneder etter symptomdebut. Klinisk debuterer den ofte med symptomer som kan forveksles med depresjon. Humørsvingninger og hukommelsestap er også vanlig. Etter hvert får pasientene problemer med balanse og koordinasjon. Innen døden inntreffer, mister de evnen til å snakke og bevege seg. Vanlige dødsårsaker er hjertesvikt, respirasjonsvikt eller pneumoni.

Creutzfeldt-Jakobs sykdom kan enten opptre sporadisk ( $84 \%)$, gjennom arv $(10 \%)$ eller i en ervervet form (6\%) (1). Sistnevnte skyldes overføring av prioner via bl.a. corneaimplantat eller nevrokirurgiske inngrep (2). I 1990-årene dukket det opp en ny type av den ervervede formen, kalt variant Creutzfeldt-Jakobs sykdom (vCJD). Til nå er ca. 200 personer i verden blitt rammet av vCJD (3), mest sannsynlig pga. inntak av mat fra storfe med kugalskap. Selv om faren for en epidemi med denne varianten ser ut til å være over, er det de senere år blitt rapportert noen tilfeller av smitte gjennom blodtransfusjoner (4). I Norge er det bare dokumentert to sikre tilfeller av den arvelige typen, to søstre bosatt på Vestlandet (5).

Prionproteinet (PrP) finnes naturlig i membranen til de fleste celler i kroppen, uten at man er sikre på dets biologiske funksjon (6). Ifølge prionhypotesen oppstår sykdommen når det naturlige, cellulære prionproteinet $\left(\mathrm{PrP}^{\mathrm{C}}\right)$ blir omdannet til den sykdomsrelaterte scrapievarianten $\left(\mathrm{PrP}^{\mathrm{Sc}}\right)$. Dette involverer hovedsakelig en strukturforandring, fra overvekt av $\alpha$-helikser til høy andel $\beta$-flak. Denne formen for PrP er mer proteaseresistent og vil derfor akkumuleres.

Omformingen fra $\mathrm{PrP}^{\mathrm{C}}$ til $\mathrm{PrPSc}^{\mathrm{Sc}}$ skjer ifølge prionhypotesen ved at det patologiske
$\mathrm{PrP}^{\mathrm{Sc}}$ virker som en form eller modell for å omdanne naturlig $\mathrm{PrP}^{\mathrm{C}}$ til $\mathrm{PrP}^{\mathrm{Sc}}(7)$ - uten at noen annen infeksiøs partikkel er involvert. Ved den arvelige formen av Creutzfeldt-Jakobs sykdom blir prionet dannet ved en genmutasjon, ved den ervervede formen blir det tilført utenfra, mens ved den sporadiske formen vet man foreløpig ikke hvordan prionet først oppstår (7). Når prosessen først er kommet i gang, vil den fortsette som en kaskadereaksjon og føre til opphopning av $\mathrm{PrP}^{\mathrm{Sc}}$ og til slutt celledød av nevroner.

Vi går her inn på tre ulike områder innen forskningen på behandling av CreutzfeldtJakobs sykdom som vi mener har vist de mest lovende resultatene.

\section{Materiale og metode}

Artikkelen er basert på ikke-systematiske søk i PubMed. Vi valgte ut originalartikler som vi syntes rapporterte om interessante og relevante resultater, i tillegg til oversiktsartikler. Referanselistene til disse artiklene ble også gjennomgått for å komplettere grunnlaget.

\section{Reduksjon av PrPC-mengden}

Siden Creuzfeldt-Jakobs sykdom mest sannsynlig skyldes at $\mathrm{PrP}^{\mathrm{C}}$ blir omdannet til $\mathrm{PrP}^{\mathrm{Sc}}$, som så akkumuleres, er en nærliggende løsning å fjerne eller redusere mengden av $\operatorname{PrP}^{\mathrm{C}}$. Det er to ulike måter å gjøre dette på: Man kan skru av ekspresjonen av prionproteingenet eller man kan hindre at proteinene blir dannet etter at genet er avlest, ved såkalt RNA-interferens (RNAi).

\section{Genmanipulasjon}

Denne metoden er blitt testet ved at man bruker mus som er genmanipulert slik at nevronene sluttet å produsere $\operatorname{PrP}^{\mathrm{C}} \mathrm{ca}$. ti uker etter

\section{Hovedbudskap}

- Nyere forskning på Creutzfeldt-Jakobs sykdom i musemodeller viser oppløftende resultater på behandling fra ulike angrepsvinkler

- Blant de mest lovende metoder er genregulering, immunisering og medikamentell behandling

- Pentosanpolysulfat har vært utprøvd på pasienter med Creutzfeldt-Jakobs sykdom, men det er uklart om behandlingen hjelper 
fødsel. De utviklet seg normalt, uten tegn til patologi (8). Forskjellen kom til syne da man en uke etter fødselen utsatte disse musene og en kontrollgruppe normale mus for scrapiesmitte. I kontrollgruppen døde samtlige mus av prionsykdom innen $12-18$ uker, mens ingen av musene uten prionprotein var døde eller hadde fått kliniske tegn på sykdom etter 52 uker (9).

Tidlige tegn på Creutzfeldt-Jakobs sykdom kan være kognitiv svikt og endret sosial atferd. Mus som fikk fjernet ekspresjonen av prionproteinet etter at de var smittet med scrapie og hadde utviklet sykdomstegn, fikk bemerkelsesverdig reversert den kognitive svikten (6).

\section{RNA-interferens}

Her bruker man en type dobbeltstrenget RNA (dsRNA) for å oppnå en sekvensspesifikk, posttranskriptorisk «gensupprime- ring». Metoden er relativt ny og kan benyttes når det er enkelte gener det er fordelaktig at ikke blir uttrykt, i dette tilfellet prionproteingenet. Det finnes flere ulike måter å få RNA-et inn i cellen på, men lentivirus har vist seg å være blant de best egnede, da de også kan integreres inn i genomet i celler som ikke deler seg (f.eks. nevroner) (10) (fig 1). En studie viste at lentivektormediert RNAi reduserte ekspresjonen av $\mathrm{PrP}^{\mathrm{C}}$ og hindret opphopningen av $\operatorname{PrP}^{\mathrm{Sc}} \mathrm{i}$ en infisert nevroblastomcellelinje (11). I tillegg viste den at mus som var genmodifisert slik at deler av cellematerialet allerede inneholdt dsRNA, levde i gjennomsnitt 214 dager etter eksponering for prioner, mot 167 dager i kontrollgruppen. Overlevelsestiden samsvarte også med graden av genmodifisering, slik at jo større andel av cellene som produserte dsRNA, desto lenger levde musene.

White og medarbeidere utviklet nylig en

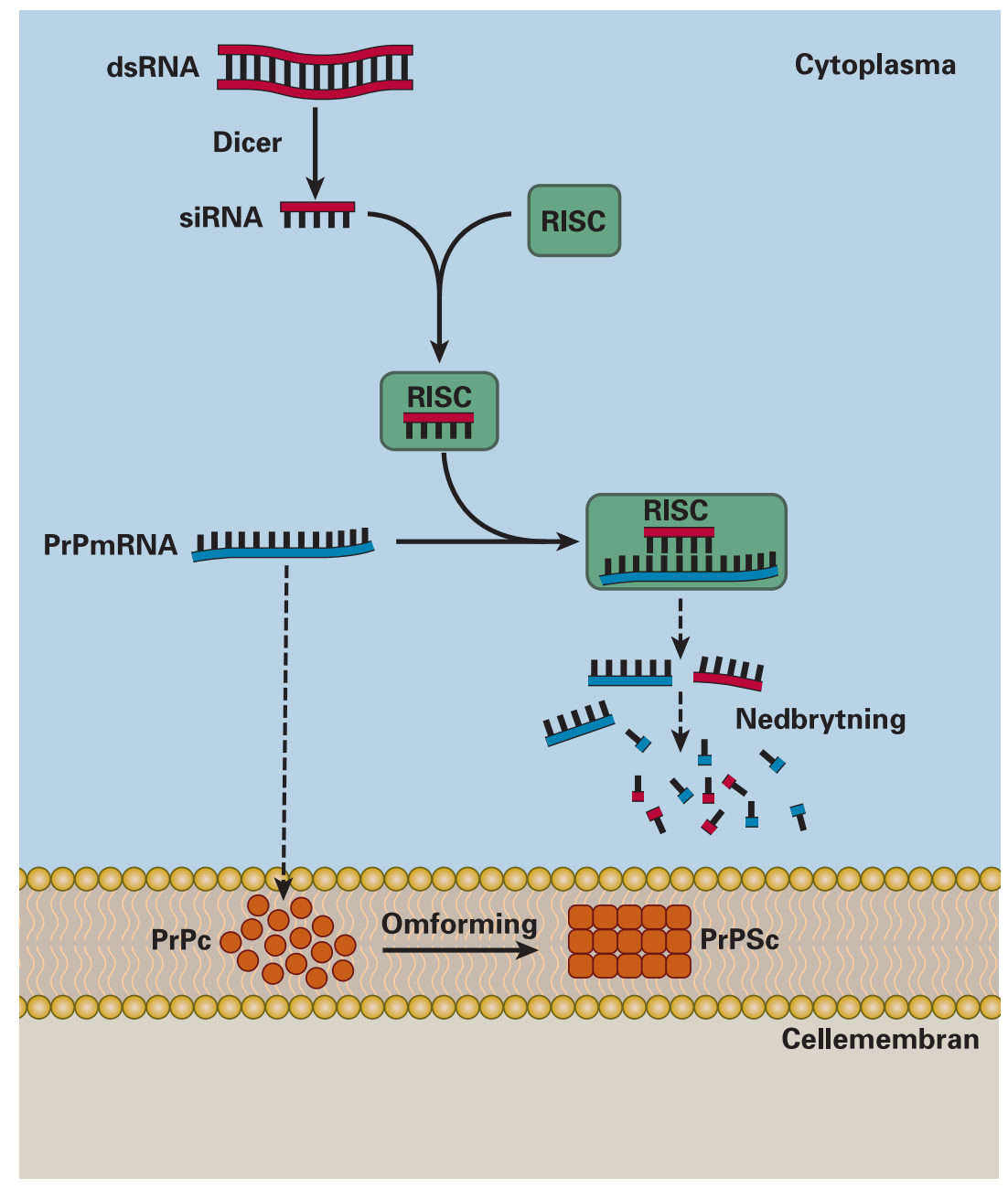

Figur 1 RNA-interferens (RNAi) er en relativt ny metode der man kan redusere ekspresjonen av spesifikke gen og hindre bestemte proteiner $i$ å dannes. Man bruker genmodifiserte virus som implanterer en dobbeltstrenget RNA-sekvens (dsRNA) i cellene. RNAi virker ved at enzymet Dicer kutter opp dsRNA til mindre biter av siRNA (small interfering RNA). Disse igjen går inn i og aktiverer RISC (RNA-induced silencing complex), som binder til og gir degradering av MRNA (messenger RNA). Pfeifer og kolleger brukte denne teknikken til å supprimere den naturlige, cellulære versjonen av prionproteinet $(P r P C)$ i nerveceller som var infisert med scrapieprioner (PrPSc) (11). Dette hindret avleiring av PrPSc og førte til økt overlevelse da de overførte metoden til en musemodell teknikk der de injiserte lentivirus med dobbeltstrenget RNA inn i hippocampus på mus som var smittet med scrapie intracerebralt (12). Disse musene levde i gjennomsnitt 105 dager etter infeksjon, mot 85 dager i kontrollgruppen (fig 2). I tillegg fikk de mindre spongiøse forandringer, nevrontap og opphopning av $\mathrm{PrP}^{\mathrm{Sc}}$. Dessuten uteble også de første atferdsforandringene forbundet med sykdommen. Disse resultatene kom etter kun én fokal injeksjon av dsRNA i hippocampus, og post mortem-undersøkelse viste mindre degenerative forandringer i nettopp hippocampus, sammenliknet med resten av hjernen. Effekten kan med andre ord mest sannsynlig økes ved gjentatte injeksjoner på ulike steder i hjernen. Forsøk gjennomføres for å forandre lentiviruset med kapselproteiner, slik at det kan foreta retrograd transport langs aksoner (13), i tillegg til bedre mekaniske metoder for injiseringen (14). Begge deler kan føre til bedre spredning av lentiviruset, og dermed antatt bedre effekt.

\section{Antistoffer}

Man kunne tenke seg å bruke immunsystemet til å bekjempe prionsykdommer enten ved hjelp av passiv immunisering (overføring av antistoffer) eller aktiv immunisering (tilføre antigen som en vaksine). Generelt vil aktiv immunisering være mest effektivt, men det har vist seg vanskelig å få til pga. den store immuntoleransen som finnes for prionproteinet. Ett unntak var en japansk studie som viste at mus som var immunisert med modifisert prionprotein fra storfe fikk forlenget tiden fra overføring av prionsmitte til utvikling av sykdom, sammenliknet med kontrollgruppen (15).

White og medarbeidere utsatte vanlige mus for scrapiesmitte, for deretter å behandle dem med gjentatte injeksjoner av antistoffer mot $\operatorname{PrP}^{\mathrm{C}}$ og $\operatorname{PrP}^{\mathrm{Sc}}$ (16). Det mest effektive antistoffet hadde større affinitet for $\mathrm{PrP}^{\mathrm{C}}$ enn for $\mathrm{PrPSc}^{\mathrm{Sc}}$, noe som er med på å styrke teorien om at $\mathrm{PrPC}^{\mathrm{C}}$ kan være det beste angrepspunktet for prionbehandling. Man antar at antistoffene virker ved å binde seg til $\operatorname{PrP}^{\mathrm{C}}$ og dermed hindrer at det kan omdannes til $\mathrm{PrPSc}^{\mathrm{Sc}}$. Gjennomsnittlig overlevelsestid for kontrollgruppen var på ca. 200 dager, mens musene som fikk antistoff overlevde mer enn 500 dager. Man så heller ingen kliniske tegn til prionsykdom på noe tidspunkt hos de musene som fikk antistoff. Den store forskjellen på denne studien i forhold til andre, er at man her så god effekt opptil 30 dager etter smitte, på et tidspunkt da sykdommen hadde etablert seg og mye PrPsc allerede var dannet. Tidligere studier oppnådde kun effekt når man startet behandlingen før eller samtidig med smitteoverføringen, noe som mest sannsynlig bare avspeilet nøytralisering av smitteagens.

Passiv immunisering hadde ingen effekt sent i sykdomsforløpet, etter at de kliniske symptomene hadde brutt ut, muligens på grunn av manglende kryssing av antistoff 
over blod-hjerne-barrieren (16). Det kan tyde på at denne behandlingsformen vil være bedre egnet til profylakse etter eksponering for prioner enn til behandling av prionsykdommer. Eventuelt kan det være mulig å oppnå effekt ved intratekal administrasjon av antistoffene.

Antistoff direkte rettet mot $\operatorname{PrP}^{\mathrm{C}}$ kan føre til flere mulige problemer. For det første er $\mathrm{PrP}^{\mathrm{C}}$ til stede i celler i så utstrakt grad i kroppen at $\mathrm{PrP}^{\mathrm{C}}$-antistoffer kan føre til uttalt destruksjon av ulike celletyper. En studie har også vist at antistoffer mot $\operatorname{PrP}^{\mathrm{C}} \mathrm{i}$ hjernen ga apoptose av hjerneceller (17).

\section{Medikamentell behandling}

Screening er blitt utført for en rekke ulike stoffer og medikamenter både i celleløse system og i cellekulturer (18). Man ser etter stoffer som kan stabilisere $\mathrm{PrP}^{\mathrm{C}}$, gjøre $\mathrm{PrP}^{\mathrm{Sc}}$ mer ustabilt, hindre omdanning av prionproteinet eller på andre måter redusere mengden av PrPSc. Problemet har ofte vært å overføre resultatene fra laboratoriet til dyr som man har smittet intracerebralt. Dette kan blant annet skyldes at medikamentene ikke klarer å krysse blod-hjerne-barrieren.

Doh-ura og medarbeidere omgikk problemet ved å tilføre ulike medikamenter til mus intraventrikulært (19). Det var imidlertid kun pentosanpolysulfat (PPS), et medikament mot interstitiell cystitt, som signifikant forlenget inkubasjonstiden. Hos mus som fikk pentosanpolysulfat, gikk det i gjennomsnitt 123 dager før de utviklet kliniske tegn på sykdommen, mot 51 dager i kontrollgruppen. Effekten var best ved høy dose og tidlig oppstart av behandling, selv om man også så effekt ved lavere doser og oppstart av behandling oppimot 40 dager etter smitteoverføring. Medikamentet virker ved å binde seg til $\mathrm{PrP}^{\mathrm{C}}$ og fører til endocytose av prionproteinet (20). Slik reduserer det tilgjengeligheten av $\operatorname{PrP}^{\mathrm{C}}$ til å bli omdannet til scrapievarianten.

\section{Humanstudier}

Pentosanpolysulfat er blitt gitt intraventrikulært til en rekke pasienter med prionsykdommer (21), deriblant sju pasienter fra Storbritannia som inngikk $\mathrm{i}$ en intervensjonsstudie (22). Det ble ikke benyttet kontrollgruppe, men overlevelsestiden viste seg å være lenger for samtlige sju pasienter enn gjennomsnittet for ubehandlede pasienter (16-64 måneder mot 13 måneder) (23). I tillegg overlevde to av pasientene med vCJD lenger enn det lengste som har vært rapportert hos ubehandlede pasienter med denne tilstanden (50 og 57 mot 39 måneder), og disse to var fremdeles i live når forsøket ble avsluttet. Selv om det var en del komplikasjoner i forbindelse med plasseringen av kanylen, så man ingen nevneverdige bivirkninger av pentosanpolysulfat. På den kliniske siden så man en forverring av allmenntilstanden under behandlingen, selv om det lave antallet pasienter og upresise måleme-

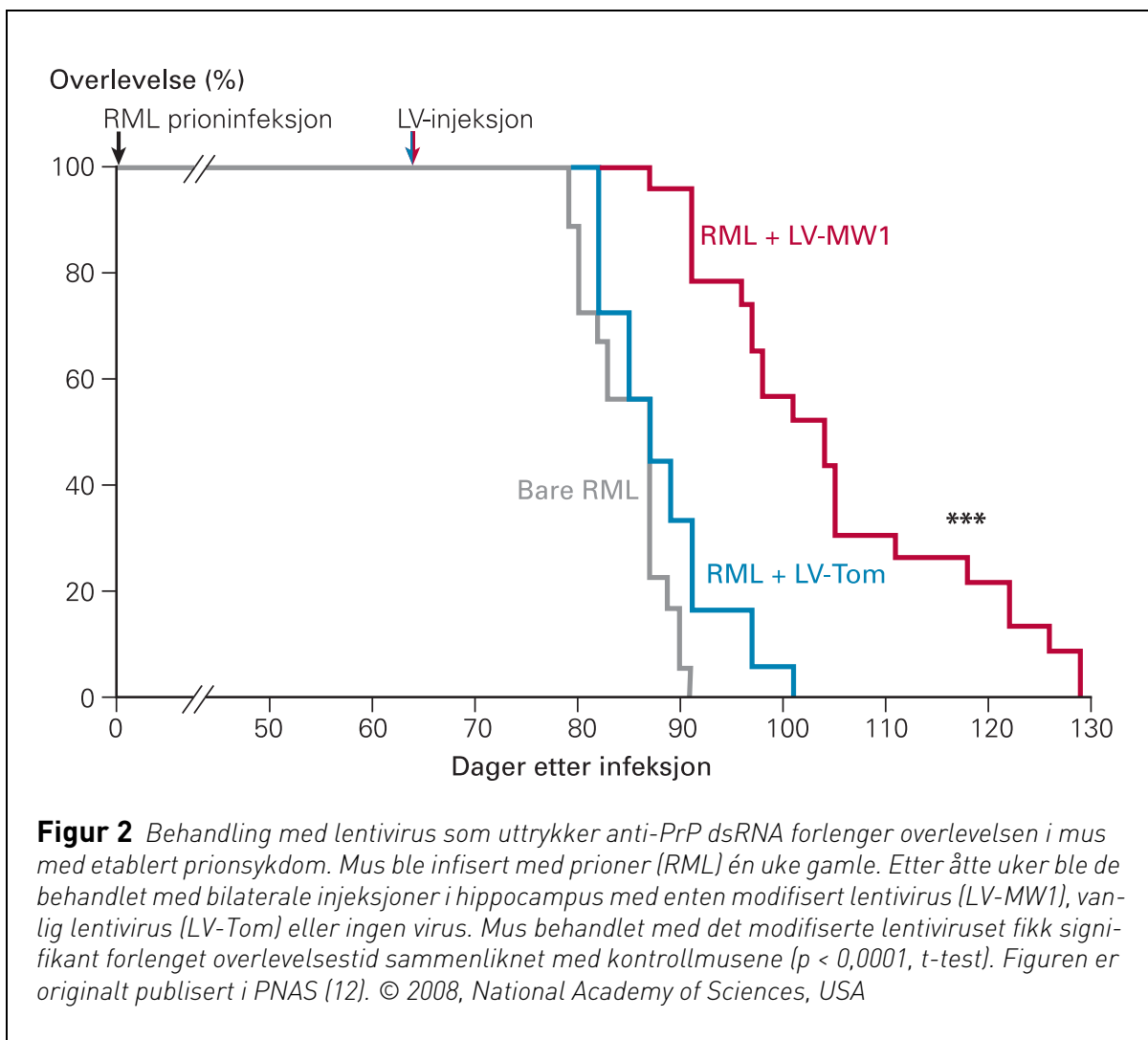

toder gjorde det vanskelig å si hvor bra eller dårlig behandlingen virket.

\section{Diskusjon}

Flere av studiene retter seg mot å svekke eller nøytralisere det naturlig forekommende prionproteinet $\left(\mathrm{PrP}^{\mathrm{C}}\right)$, forstadiet til det sykdomsfremkallende $\mathrm{PrPSc}^{\mathrm{Sc}}$. Mallucci og medarbeidere viste at mus uten $\mathrm{PrP}^{\mathrm{C}}$ ikke utviklet sykdom etter eksponering for scrapiesmitte (9). Spørsmålet blir da om dette kan gjøres trygt og uten bivirkninger. Mens enkelte studier viste at mus uten $\operatorname{PrP}^{\mathrm{C}}$ er levedyktige og med tilnærmet normal funksjon $(8,24)$, rapporterte Criado og medarbeidere at musene uten $\operatorname{PrP}^{\mathrm{C}}$ hadde problemer med å lære romfølelse og hadde redusert kort- og langtidssynaptisk plastisitet i gyrus dentatus (25). Dette tyder på at $\operatorname{PrP}^{\mathrm{C}}$ er nødvendig for normal hippocampusavhengig læring. Man fant ikke disse forandringene hos yngre mus født uten $\operatorname{PrP}^{\mathrm{C}} \mathrm{i}$ alderen 25 dager - fire måneder (26), noe som kan støtte hypotesen om at $\operatorname{PrP}^{\mathrm{C}}$ er med på å beskytte nevronene mot oksidativt stress (27). På tross av potensielle alvorlige bieffekter kan man argumentere for behandlingsforsøk på mennesker, siden Creutzfeldt-Jakobs sykdom er en raskt dødelig sykdom.

Mange av medikamentene virker dårlig når behandlingen starter sent $i$ sykdomsforløpet. Dermed kan det bli vanskelig å oppnå god effekt hos mennesker, ettersom pasientene først oppsøker medisinsk hjelp etter at de nevrologiske symptomene har debutert. Slik vil også forbedring av diagnostiske metoder kunne spille en viktig rolle for behand- lingsresultatet. Foreløpig er det kun hos dem med den arvelige varianten av CreutzfeldtJakobs sykdom, der man kan påvise en genetisk mutasjon, at man i teorien kan starte behandling før det har oppstått uttalt nevrologisk celledød. Eksperimentell behandling på klinisk friske personer vil likevel være etisk vanskelig. Siden menneskehjernen er såpass mye større enn musehjernen, er også tilstrekkelig distribusjon $i$ vevet et problem som må løses.

Tolking av resultatene fra kliniske forsøk med pasienter med Creutzfeldt-Jakobs sykdom kan også by på problemer, da overlevelsestiden ubehandlet i så stor grad varierer individuelt, fra få måneder til flere år. Når man i tillegg har et tynt pasientgrunnlag, vil usikkerheten ved resultatene fort bli stor. I noen tilfeller vil også livskvaliteten og bevissthetsnivået være så sterkt nedsatt at videre livsforlengende behandling ikke kan rettferdiggjøres.

\section{Konklusjon}

Forskningen på behandlingsmetoder for Creutzfeldt-Jakobs sykdom har gjort store fremskritt de siste årene. Tidligere fokuserte man mye på å screene for ulike medikamenter som kunne ha effekt, uten å oppnå noen særlige resultater. I det siste har man ved hjelp av ulike former for genterapi, RNAi, immunisering og intraventrikulært injiserte medikamenter oppnådd gode resultater i forsøksdyr $(6,12,19)$. I enkelte forsøk har alle dyrene som ble behandlet holdt seg friske gjennom hele deres forventede levetid ( 9 , 16). Man har også overført en av behand- 
lingsmetodene, medikamentet pentosanpolysulfat, til pasienter med Creutzfeldt-Jakobs sykdom, med lovende resultater (22).

Selv om ingen har klart å finne eller utføre en helbredende behandling for pasienter med Creutzfeldt-Jakobs sykdom, finnes det nå teknikker og kunnskap som gir et godt grunnlag for videre forskning.

Oppgitte interessekonflikter: Ole-Bjørn Tysnes har mottatt honorar for forelesninger og fagmøter samt reisestøtte fra de fleste aktører innen farmasøytisk industri som er knyttet til fagfeltet nevrologi. Torger Stølsmark har ingen oppgitte interessekonflikter.

\section{Litteratur}

1. Ladogana A, Puopolo M, Croes EA et al. Mortality from Creutzfeldt-Jakob disease and related disorders in Europe, Australia, and Canada. Neurology 2005; 64: 1586-91.

2. Will RG. Acquired prion disease: iatrogenic CJD, variant CJD kuru. Br Med Bull 2003. 66. 255-65.

3. Pocchiari M. Prevalence of variant CJD in the UK. BMJ 2009; 338: b435.

4. Llewelyn CA, Hewitt PE, Knight RS et al. Possible transmission of variant Creutzfeldt-Jakob disease by blood transfusion. Lancet 2004; 363: 417-21.

5. Farbu E, Tysnes OB, Mork S et al. Two Norwegian sisters with late onset Creutzfeldt-Jakob disease caused by the E200K mutation. J Neurol 2007; 254 : 262-3

6. Mallucci GR, White MD, Farmer M et al. Targeting cellular prion protein reverses early cognitive deficits and neurophysiological dysfunction in prioninfected mice. Neuron 2007; 53: 325-35.

7. Prusiner SB. Prions. Proc Natl Acad Sci U S A 1998; 95: 13363-83
8. Mallucci GR, Ratte S, Asante EA et al. Post-natal knockout of prion protein alters hippocampal CA1 properties, but does not result in neurodegeneration. Embo J 2002; 21: 202-10.

9. Mallucci G, Dickinson A, Linehan J et al. Depleting neuronal PrP in prion infection prevents disease and reverses spongiosis. Science 2003; 302 $871-4$.

10. Li CX, Parker A, Menocal E et al. Delivery of RNA interference. Cell Cycle 2006; 5: 2103-9.

11. Pfeifer A, Eigenbrod S, Al-Khadra S et al. Lentivector-mediated RNAi efficiently suppresses prion protein and prolongs survival of scrapie-infected mice. J Clin Invest 2006: 116: 3204-10.

12. White MD, Farmer M, Mirabile I et al. Single treatment with RNAi against prion protein rescues early neuronal dysfunction and prolongs survival in mice with prion disease. Proc Natl Acad Sci U S A 2008. 105: 10238-43.

13. Kato S, Inoue K, Kobayashi K et al. Efficient gene transfer via retrograde transport in rodent and primate brains using a human immunodeficiency virus type 1-based vector pseudotyped with rabies virus glycoprotein. Hum Gene Ther 2007: 18: $1141-51$.

14. Oh S, Odland R, Wilson SR et al. Improved distribution of small molecules and viral vectors in the murine brain using a hollow fiber catheter. J Neurosurg 2007; 107: 568-77.

15. Ishibashi D, Yamanaka $\mathrm{H}$, Yamaguchi $\mathrm{N}$ et al. Immunization with recombinant bovine but not mouse prion protein delays the onset of disease in mice inoculated with a mouse-adapted prion. Vaccine 2007; 25: 985-92.

16. White AR, Enever P, Tayebi M et al. Monoclonal antibodies inhibit prion replication and delay the development of prion disease. Nature 2003; 422: $80-3$

17. Solforosi L, Criado JR, McGavern DB et al. Crosslinking cellular prion protein triggers neuronal apoptosis in vivo. Science 2004: 303: 1514-6.

18. Kocisko DA, Baron GS, Rubenstein R et al. New inhibitors of scrapie-associated prion protein for- mation in a library of 2000 drugs and natural products. J Virol 2003; 77: 10288-94.

19. Doh-ura K, Ishikawa K, Murakami-Kubo I et al. Treatment of transmissible spongiform encephalopathy by intraventricular drug infusion in animal models. J Virol 2004: 78: 4999-5006.

20. Shyng SL, Lehmann S, Moulder KL et al. Sulfated glycans stimulate endocytosis of the prion protein PrPC, in cultured cells. J Biol Chem 1995; 270: $30221-9$

21. Rainov NG, Tsuboi Y, Krolak-Salmon P et al. Experimental treatments for human transmissible spongiform encephalopathies: is there a role for pentosan polysulfate? Expert Opin Biol Ther 2007 7: 713-26.

22. Bone I, Belton L, Walker AS et al. Intraventricular pentosan polysulphate in human prion diseases: an observational study in the UK. Eur J Neurol 2008. 15: 458-64.

23. Pocchiari M, Puopolo M, Croes EA et al. Predictors of survival in sporadic Creutzfeldt-Jakob disease and other human transmissible spongiform encephalopathies. Brain 2004; 127: 2348-59.

24. Roesler R, Walz R, Quevedo J et al. Normal inhibitory avoidance learning and anxiety, but increased locomotor activity in mice devoid of $\operatorname{PrP}(\mathrm{C})$. Brain Res Mol Brain Res 1999; 71: 349-53.

25. Criado JR, Sanchez-Alavez M, Conti B et al. Mice devoid of prion protein have cognitive deficits that are rescued by reconstitution of $\mathrm{PrP}$ in neurons Neurobiol Dis 2005; 19: 255-65.

26. Curtis J, Errington M, Bliss T et al. Age-dependen loss of PTP and LTP in the hippocampus of PrPnull mice. Neurobiol Dis 2003; 13: 55-62.

27. Brown DR, Schulz-Schaeffer WJ, Schmidt B et al. Prion protein-deficient cells show altered response to oxidative stress due to decreased SOD-1 activity. Exp Neurol 1997; 146: 104-12

Manuskriptet ble mottatt 22.11. 2008 og godkjent 7.1. 2010. Medisinsk redaktør Trine B. Haugen. 